\title{
The "Higher" Age of Consent and the concept of Sexual Exploitation
}

Professors Alisdair A. Gillespie and Suzanne Ost.

Lancaster University Law School

The age of consent in England is 16. Except it is not always. It is ordinarily the age of 16 but since 2000, there has been a higher age of consent (18) for certain sexual activities. Originally this was where there was thought to be a position of trust (Sexual Offences (Amendment) Act 2000), but it then was extended to other forms of exploitation, including prostitution and child pornography.

This chapter will consider the issue of the higher age of consent and consider whether it is truly protecting children or whether it is an example of a paternalistic society governing what sexual activities a 16 or 17-year-old child can engage with and/or who their sexual partner is. After a critical exploration of the age of consent, an analysis will be made of the types of situations where the higher age is engaged and why it is not engaged in other exploitative contexts (such as employment). We will also consider whether the criminal law's restrictions can be justified or whether they may infringe the older child's right to a sexual identity. We then engage with philosophical understandings of the concept of sexual exploitation and consider what the crux of the issue (justifying criminalisation) should be. Ultimately, we will argue that a higher age of consent can be justified in the context of exploitative relationships, with the existence of exploitation being ascertained through a consideration of the circumstances of the relationship rather than the relationship falling under a definitive statutory list.

\section{Age of Consent}

A useful starting point is to consider what an age of consent is and what its purpose is. It is often said that the age of consent in England \& Wales is 16 but that is not strictly true. The age varies depending on the particular relationship between the parties engaging in sexual activity. Indeed it is this variance which forms the discussion of this chapter.

\section{Consent?}

The term 'age of consent' is itself controversial and it has been suggested that what is created is an 'age of liability' for the offender rather than an age of consent. ${ }^{1}$ The context of this comment is that the age of consent arguably has little to do with consent and is instead the establishment of an age at which the law decides that a child is allowed to have sex. This is a point that is taken up by other commentators.

Consent is ordinarily considered to be a concept that relates to self-determination, ${ }^{2}$ the right to make self-governing decisions about one's life. $^{3}$ It is the capacity of an individual to give

$1 \quad$ K. Walsh 'Images of Childhood, Adolescent Sexual Reality and the Age of Consent' in H. Gavin and J. Bent Sex, Drugs and Rock \& Roll: Psychological, Legal and Cultural Examinations of Sex and Sexuality (2010, InterDisciplinary Press) 47-58 at 48.

2 In the context of medical law, see, for example, the much-quoted statement from Cardozo J. in Schloendorff $v$ New York State Hospital (1914) 105 NE 92 that '... every human being of adult years and sound mind has a right to determine what shall be done with his own body; and a surgeon who performs an operation without his patient's consent, commits an assault...', at 93.

3 J. Coggon and J. Miola, ‘Autonomy, Liberty and Medical Decision-making' (2011) 70 Cambridge Law Journal $523-547$ at 524. 
permission to do something that makes their consent valid. ${ }^{4}$ In the context of sex, this would mean that they have the capacity to understand what sex is, what it means and the ability to decide whether they want to have sexual contact with another. However, capacity is a very subjective concept. It must vary between individuals because of their developmental differences. The significance of developmental capacity is reflected in the approach taken to consent to treatment and capacity in medical law when a doctor is faced with an older 'Gillick competent' child. In such a case, the status-based presumption that children lack capacity is rebutted provided the child can establish that she has the requisite maturity to possess decision-making capacity. ${ }^{5}$

The age of consent cannot therefore realistically relate to the capacity of an individual. As capacity will differ between individuals, so will the age at which they are capable of making that decision. This has been considered to create problems for the law because it means that a clear statement of rule cannot be set out - "you will not have sexual contact with a child under $n$ years of age" - because, if it were based on capacity, that would not follow. Someone (n-2) may have the capacity to consent and yet someone else $(n+3)$ may not. Of course, not everyone would agree that this is a problem. In the context of adult sexual assaults, there is similar variance. Different people will consent to different actions and thus an individual will need to ascertain that $\mathrm{V}$ consents before having sexual contact with him or her. Could it be said that the same should apply to some children? Is it not more appropriate that an individual wishing sexual contact with an adolescent ${ }^{6}$ should ascertain whether the child understands the nature of the activity, any potential consequence (eg STIs, pregnancy, loss of virginity, cultural or other societal factors) and ascertain their desire to connect sexually?

The current age of consent does not do this and therefore it realistically moves us away from factual consent and instead steers us towards legal consent. The age of consent means that a person under the prescribed age cannot, as a matter of law, give consent, irrespective of whether they have the capacity to make that decision and the desire to do so. The law not only fails to recognise that decision, it prohibits this decision from being acted upon. Anyone who has sexual contact with that child will commit a criminal offence. ${ }^{7}$

However, although the age of consent is supposed to render factual consent irrelevant it does not always do this. So, for example, under English law a person commits the offence of rape of a child if he has sexual intercourse with a child under the age of $13 .{ }^{8}$ The offence is one of strict liability and it is therefore irrelevant whether the offender knew the age of the child or indeed whether the child gave factual consent. Whilst there is also the offence of rape, ${ }^{9}$ which applies irrespective of the age of the victim, theoretically there should be no need to use the offence where the victim is aged under 13 because proving the offence under s.5 is simpler. For the offence of rape under s.1, it is necessary to prove an absence of factual consent ${ }^{10}$ and also the

\footnotetext{
$4 \quad$ 'Law makes the power of individual choice legally contingent on competence. The right to make decisions in matters such as marriage, contractual relations, voting, testamentary disposition, and health care depends on being legally competent.' S. Stefan, 'Silencing the Different Voice: Competence, Feminist Theory and Law' (1993) 47 University of Miami Law Review 763-815 at 765.

$5 \quad$ See Gillick $v$ West Norfolk and Wisbech AHA [1986] 1 AC 112 and R (On the Application of Axon) $v$ Secretary of State for Health (Family Planning Association intervening) [2006] EWHC 37 (Admin).

6 In this chapter we do not propose to discuss the idea that a child of any age can consent as we believe such argument is unarguable. Instead the discussion relates to children aged between 14 and 18 (14 being the youngest age often referred to as a potential age of consent).

See, most notably, the offences contained in ss.5-15, Sexual Offences Act 2003.

Sexual Offences Act 2003, s.5.

Sexual Offences Act 2003, s.1.

D.C. Ormerod and K. Laird Smith \& Hogan's Criminal Law (14 th Edn, 2015: Oxford) at 852.
} 
fact that $\mathrm{D}$ did not believe that $\mathrm{V}$ consented. ${ }^{11}$ Notwithstanding this fact and that the CPS charging guidance specifically states that $\mathrm{s.1}$ should not be used, ${ }^{12}$ there have been occasions when the offence of s.1 has been used even when the victim is aged under $13 .{ }^{13}$ This would seem to suggest that even the law does not view the age of consent as being about consent but, rather, about the liability of the offender. By prosecuting rape, rather than the rape of a child, the law is admitting that factual consent is more important than legal consent and that the absence of factual consent is more serious than the absence of legal consent. There is logic to such a distinction but it does raise questions about whether this could create 'classes' of victims, especially if sentencing differs between the offences. This would be problematic where it was unclear whether a child factually consented meaning the prosecution would face a decision as to whether to accept a guilty plea in respect of the 'lesser' offence or to proceed to trial on the other.

\section{Identifying an age}

If, for simplicity, it is decided to have an age of consent (which is the pattern that most developed countries have adopted ${ }^{14}$ ) then the question becomes what age is chosen? And indeed how is that age chosen. The setting of the age of 16 as the (ordinary) age of consent in England \& Wales occurred for reasons of political pragmatism rather than a considered societal response.

The first reference to an age of consent is arguably to be found in the first Statute of Westminster (1275) where a misdemeanour was created of ravishing 'a maiden within age' which Blackstone contended meant the age of marriage, then set at $12,{ }^{15}$ the offence applying to those victims under that age. In 1576 a felony was created of having carnal knowledge of a woman child under the age of $10 .{ }^{16}$ There is some confusion over what this meant, with Hale contending it meant that the age of consent remained at 12 but that stronger punishment was imposed on those who abused a child under the age of 10 (as that was a felony). However, some countries who took their laws from England adopted a different approach and decided that the age of consent became 10 (in effect ignoring the Statute of Westminster).

The age then remained relatively stable until the $19^{\text {th }}$ Century when a series of stories in the Pall Mall Gazette describing how widespread child prostitution was led to public disquiet, causing Parliament to act to increase the age of consent to $16 .{ }^{17}$ However, there was no clear rationale for choosing the age of 16. It was not based on any scientific evidence, it was a reaction to what had happened and was an age that politicians compromised on. Similarly, when the age for (male) homosexual intercourse was set at 21 following the decriminalisation of consensual buggery, ${ }^{18}$ the choice of age was not really the product of any scientific or sociological stance but was a political reaction to the decriminalisation and a belief that the youth and young persons should not be permitted to engage in such activity for fear of being corrupted. ${ }^{19}$ In 1994 , the age

\footnotetext{
11 Save where one of the irrebutable presumptions of consent apply (see Sexual Offences Act 2003, s.76).

12 See http://www.cps.gov.uk/legal/p to r/rape and sexual offences/soa 2003 and soa 1956/\#a16 (Accessed 30 October 2015).

$13 \quad$ See, for example, $R v J M$ [2015] EWCA Crim 1638;

$14 \quad$ J. Rudolph 'Rape and Resistance: Women and Consent in Seventeenth-Century English Legal and Political 'Thought' (2000) 39 Journal of British Studies 157-184 at 173.

15 Ibid. at 178

Benefit of the Clergy Act 1575.

Criminal Law (Amendment) Act 1885.

Sexual Offences Act 1967, s.1.

The age of 21 was chosen because at that time the age of majority was 21 . Thus it was decided that homosexual acts were decriminalised when it involved adults.
} 
was reduced to the age of $18^{20}$ even though this created a position whereby heterosexual and (male) homosexual sex were treated differently. Again, the age of 18 was a political choice/compromise ${ }^{21}$ and not a reasoned decision. When the age of consent was finally equalised between homosexual and heterosexual acts ${ }^{22}$ there was no real consideration of whether 16 was the correct age for the age of consent. That is, the age for homosexual activities was reduced to 16 to introduce equality, not because there was a rational argument for 16 being the appropriate age for consent.

One of the difficulties in this area is that identifying an age is, and always has, been difficult. There is no identifiable point at which we can point to someone and say "child". International law, or at least some parts of it, consider a child to be anyone under the age of $18 .{ }^{23}$ However, it is unlikely that many 17 -year-olds would be particularly impressed at being called a child. Also, we cannot suggest a 17 -year-old is the same as a 17 -month-old. The most obvious distinction between a child and adult would be puberty, particularly in respect of females. The onset of menses marks the point at which the female is able to bear a child. Historically this was often considered the point at which a girl became a woman ${ }^{24}$ and it is perhaps one reason why the age of 12 was chosen in the Statute of Westminster. A difficulty with choosing puberty is twofold. The first is that the age at which a person goes through puberty differs between individuals. Perhaps this is not problematic since there are at least obvious signs a person has gone through puberty, although person $\mathrm{A}$ is not necessarily going to know whether person $\mathrm{B}$ has experienced the menarche. The second problem is that puberty is a physical transformation but there is nothing that indicates that a child is emotionally able to have sex. When 'childhood' is considered less as a physical issue and more of a social construct, ${ }^{25}$ the emotional maturity and ability of a child becomes relevant, which returns us to capacity. Separate to these two problems is the fact that whilst puberty may act as a distinctive marker for females, there is no masculine equivalent to the menarche meaning puberty would be an even more problematic distinction for boys. ${ }^{26}$

If we set aside physical factors to decide who is a child then can the social sciences assist us with the question of what makes someone a child rather than an adult? The concept of childhood has long been considered a social construct and the late $-19^{\text {th }}$ and $20^{\text {th }}$ centuries saw increasing focus on psychology and the belief that childhood could be explained through maturation by development. ${ }^{27}$ However the difficulty with this is that it returns us to subjectivity. Children develop at different rates and thus it can be questioned whether this assists us with identifying an age of consent because it brings us back to the difficulties of capacity discussed above.

Of course the pragmatic solution would be to adopt a compromise. A uniform age of consent brings simplicity. It is simple to understand for both children and adults. Whilst, of course, capacity remains importance since without the capacity to consent there cannot be any factual

$20 \quad$ Criminal Justice and Public Order Act 1994, s.143.

21 Given the age of majority had been reduced to 18 in 1970 (Family Reform Act 1969, s.1) it is perhaps surprising that it took so long for the age to be reduced but it also demonstrates why 18 was chosen: homosexual acts remained only decriminalised when it involved adults.

22 Sexual Offences (Amendment) Act 2000, s.1.

23 See, most notably, the United Nations Convention on the Rights of the Child.

$24 \quad$ A useful discussion on the place of puberty is given by M.C. Seto Pedophilia and Sexual Offending Against Children (2008, American Psychological Association) at 4-6.

25 M.L. King, 'Concepts of Childhood: What We Know and Where We Might Go' (2007) 60 Renaissance Quarterly 371-407, at 402.

26 Historically it was not uncommon for a 'boy' to become a 'man' after his first act of (heterosexual) intercourse (which would cause a logic loop if this was considered to be the marker for sexual consent) or, in some cultures, it could be their first hunt or kill.

27 M. Waites The Age of Consent (2005, Palgrave MacMillan) at 12. 
consent, a uniform age is normally set at a point in time by which the majority of individuals of that age would have this capacity. It renders prosecutions slightly easier as it removes the issue of consent, something that has always been considered difficult to prove. ${ }^{28}$ If the prosecution needed to not only address factual consent but also capacity then it is likely that their task would be considerably harder.

However the simplicity of adopting a uniform age of consent also causes the weakness of arbitrariness. The age chosen has to be a compromise and as it is a legal issue it becomes as much a question of politics as child development. Across Europe there is a broad range of ages of consent ${ }^{29}$ although the most common ages are 15 and 16. Waites, in his excellent text on the age of consent, ultimately concludes that a uniform age is most appropriate but suggests the age of 14 , although subject to a 'buffer' under the age of $16 .{ }^{30}$ It is not our purpose in this chapter to consider the appropriate age but it is submitted that if any reform is to be introduced it should be based on scientific understandings of the development of children.

A slightly different, but extremely relevant, question for us is whether there should be a single age of consent for all circumstances or whether we recognise that some situations require a different age. The logic of introducing two ages would be to recognise that children may have capacity to make decisions of consent in respect of situation $x$ but might not have the capacity to deal with situation $y$. This perhaps recognises that the decision to have sexual intercourse with a child of the same age may raise very different issues to the decision to have sexual intercourse with someone in authority. To some, the question is superfluous as the sole issue should be whether someone has consented or not. However focusing exclusively on the existence or nonexistence of consent carries with it two potential disadvantages. The first is that consent has proven a particularly difficult concept over the years to prove, particularly in contexts that do not meet traditional stereotypes of non-consent. ${ }^{31}$ Where there is ostensible consent then it is likely to be even more difficult to persuade a tribunal of fact that this ostensible consent was vitiated. ${ }^{32}$ The second disadvantage is that it is more difficult to deter potential harmful contact by relying on consent. Creating a specific criminal offence that labels certain types of behaviour as criminal carries with it a degree of certainty and puts people on notice that such behaviour is considered illicit. Relying on the definition of consent however does not bring this clarity, not least because the average person is unlikely to be familiar with decisions of the courts.

Perhaps with these concerns in mind, as has been noted, England \& Wales has adopted the position of having a 'higher' age of consent for some situations and it is to that which we now turn.

\section{The "Higher" age of consent}

\footnotetext{
28 For a good discussion on some of the problems consent has proven (in general) see C. McGlynn 'Feminist activism and rape law reform in England and Wales: A Sisyphean struggle?' in C. McGlynn and V. Muno Retbinking Rape Law: International and Comparative Perspectives (2010, Routledge) pp.139-153.

$29 \quad$ From 14 (Germany) to 18 (Malta).

30 Waites, n 27 above, at 238. The 'buffer' is that decriminalisation occurs when the parties are within 2 years of each other when either party is below the age of 16. So, for example, D (aged 17) could lawfully have sex with V (aged 15) but E (aged 20) could not lawfully have sex with W (aged 15).

31 For example, criminal law textbooks have long debated the matter of consent in the context of the perceived difference between a threat ('if you do not have sex with me I will sack you') and a promise ('if you have sex with me I will give you a pay rise') (see, for example, Ormerod and Laird, n 10 above, at 823).

32 See, for example, L. Ellison and V. Munro 'Jury deliberations and complainant credibility in rape trials' in McGlynn and Munro, n 28 above, at 281-293.
} 
The 'higher' age of consent applies to limited circumstances and it is necessary to briefly identify these circumstances and how they came to apply.

Sexual Offences (Amendment) Act 2000.

The Sexual Offences (Amendment) Act 2000 was the culmination of legislative attempts that dated back to $1998 .{ }^{33}$ As part of a process to equalise the age of consent between heterosexual and homosexual acts, the Sexual Offences (Amendment) Bill 1998 sought to introduce new offences of abuse of a position of trust. ${ }^{34}$ However whilst the Bill was passed by the House of Commons it was rejected by the House of Lords (primarily due to resistance to the idea of equalising the age of consent). Reintroduced the following year it was again rejected by the House of Lords. On its third passage through the House of Commons, the Parliament $\mathrm{Act}^{35}$ was invoked and it received Royal Assent without the need to pass the House of Lords.

The reduction in age to 16 was discussed briefly above and not strictly necessary to our discussion here. What is of interest however is that alongside reducing the age of consent for homosexual acts to 16, it introduced a new offence termed 'abuse of a position of trust'. ${ }^{36}$ Much of the discussion that accompanied the reduction in the age of consent for homosexual acts concerned the belief that 16 and 17-year-old boys would be 'preyed' upon by older men. ${ }^{37}$ One response to this concern was the new abuse of trust provision, although it should be noted that this applied equally to male and female victims. ${ }^{38}$

A position of trust was defined as follows:

- D looks after $\mathrm{V}$ in an institution by virtue of an order of a court.

- $\mathrm{V}$ is resident in accommodation pursuant to the Children Act 1989 and $\mathrm{D}$ is employed to look after such persons.

- $\mathrm{V}$ is resident in a hospital, a residential care home, community home or a home provided under the Children Act 1989 and D is employed to look after such persons.

- D looks after persons receiving full-time education at an educational institution and V attends that institution. ${ }^{39}$

It has been suggested that the phraseology of the 2000 Act is that it is the position of trust that is abused rather than a child ${ }^{40}$ and this would seem to be the case. Section 3(1) criminalises sexual intercourse or sexual activity with a child under 18 if...he is in a position of trust in relation to that person'. As the position of trust is defined as above, it follows that the emphasis of the action is not on whether $\mathrm{D}$ abused the trust of $\mathrm{V}$ but whether $\mathrm{D}$ was in a position whereby that trust could be abused. That may seem the same thing but it is very different. It is irrelevant

33 The 2000 Act was initially introduced in 1998. It was defeated in two Parliamentary sessions and the Parliament Act 1911 was invoked to allow it to be given Royal Assent without it being passed by the House of Lords.

For a useful background on the Bill see 'The Sexual Offences (Amendment) Bill: "Age of consent" and abuse of a position of trust' (House of Commons Research Paper 99/4 of 21 January 1999'.

Parliament Acts of 1911 and 1949.

Sexual Offences (Amendment) Act 2000, s.3.

Waites provides a useful summary of the passage of the Act (Waites, n 27 above, at 183-207).

Interestingly, little discussion was spent noting that older men could quite legally prey on 16 and 17 year old girls or, indeed, older women could have preyed upon 16 and 17 year old boys, although a rare mention was made by Baroness Gould of Potternewton (Hansard, HL Deb, vol 612, col 113 (11 April 2000)).

39 Sexual Offences (Amendment) Act 2000, ss.4(2)-(5).

$40 \quad$ Waites, $\mathrm{n} 27$ above, p.191. 
whether D actually abused his position of trust over $\mathrm{V}$, it is merely that he was in a position to do so.

The term 'abuse' has been the subject of some criticism, with Waites suggesting the term was used after pressure from feminists and child protection advocates. ${ }^{41}$ The difference between 'abuse' and 'exploitation' is very interesting in terms of linguistics and it is something that we return to below, when we put forward an argument that English law has focused on the wrong concept and that 'exploitation' is a more pertinent concept to tackle this behaviour.

What is notable about these positions is that they were very restrictive in scope. For example, education seemed to have been covered but only if the student was in full-time education. Moreover, at the time the 2000 Act was in force, the age a child could leave school was 16 which potentially led to a loophole. Let us take two examples:

$\mathrm{V}$ is taking A-level History and has become emotionally attached to his $6^{\text {th }}$ form history teacher, Ms X. They eventually have sexual intercourse.

$\mathrm{V}$ has left school and is working in a training scheme. As part of that she has to attend a secretarial qualification at her local sixth-form college. During one of her sessions she becomes close to her instructor, Ms X, and ultimately has sex with her.

Is there any difference between these two examples? In both $\mathrm{V}$ is being instructed by an adult Ms X. In both situations $\mathrm{V}$ has sexual contact with Ms X but only in the first example would an offence under the SO(A)A 2000 have been committed.

Similar problems arose with other positions. So, for example, a position of trust exists for those who look after a child detained by order of the court (eg an officer within a young offender institution) but a probation officer would not be covered because the child is not in detention. ${ }^{42}$ Yet a parole officer could have particular influence over a child, particularly where she is scared that she could be sent back to court for breaching a non-custodial sentence. Likewise a doctor or nurse treating a patient in a hospital is covered by the law but a GP is not. Potentially a GP may actually be in a greater position of trust as it is possible they will know their parents or other members of the local society and may have had a longer term relationship with the child.

\section{Indecent photographs of children}

Section 1 of the Protection of Children Act 1978 as amended states that it is, inter alia, an offence to take, make or distribute an indecent photograph of a child. For these purposes, 'child' is defined as $18,{ }^{43}$ which was increased from 16 in $2003 .{ }^{44}$ The decision to increase the age of 'a child' for these purposes was taken ostensibly to comply with international law. ${ }^{45}$

The provision to increase the age was passed with little critical debate, with most simply taking it as read that it was necessary to ensure that children were protected. Much mention was made in Parliament of the disgusting nature of child pornography, including statements of revulsion at

$41 \quad$ Waites, $\mathrm{n} 27$ above, at 192.

42 It is possible that sexual activity by such persons would be considered to breach the (common law) offence of misconduct in a public office but that is not recognised as a sex offence and also suggests that the 'victim' of the offence is the public office rather than a potentially vulnerable youth.

43 Sexual Offences Act 1967, s.1(1).

$44 \quad$ Sexual Offences Act 2003, s.45.

45 Hansard, HL Deb, vol 616 col 1566, 04 October 2000. 
images that had been shown to Parliamentarians. However what is not clear is whether such images included 16 and 17-year olds. Indeed it is probably more likely that such images would not have been included because the vast majority of child pornography involves younger children. ${ }^{46}$ This point was picked up by some, although not particularly strongly. In the House of Lords, Lord Monson noted that the overarching purpose of the Act was to tackle paedophiles and yet they would not be interested in 16 and 17 -year olds. ${ }^{47}$ Setting aside the precise definition of a paedophile, ${ }^{48}$ there is some merit to what was being said here. The mischief behind the Act was to tackle those who were taking or distributing images of children being abused and exploited, ${ }^{49}$ and the strict liability approach to age was justified on the basis that it (ordinarily) documents a criminal act. ${ }^{50}$

Changing the age of 'a child' to 18 breaks this link to a criminal act. It is not necessarily a legal wrong to have sexual contact with a 16 or 17 year old child. Whilst this chapter will, in the next section, highlight some situations when such conduct would be illegal, the general rule is that sexual intercourse with a 16 or 17 year old is not illegal. Therefore why create a situation in which two 16-year-olds can have sex with each other but not photograph each other? Lord Monson noted that there could be a justification for criminalising commercial photographs of 16 and 17 year olds but this is not what has happened. Instead Parliament chose to criminalise all photographs of 17 and 18-year olds, even when they take them of themselves.

One justification for increasing the age to 18 that was advanced by some NGOs concerned the maturity of adolescents and the permanent nature of images. The issue of maturity has already been raised in the context of the age of consent and it has been noted that it is difficult to base any decision on a uniform understanding of maturity as no such thing exists. Children and young people mature at different rates and there is no evidence to show that an 18 year-old is more mature than a 16-year-old. Whilst it is undoubtedly true that sexualised photographs are a permanent record ${ }^{51}$ there are many other permanent dangers (or at least dangers with long-term effects) involved in sexual activity, including sexually-transmitted diseases and pregnancy, and yet there has been no (serious) call for the age of consent for sex to be increased. Whilst it was not true at the time the decision was taken to raise the age of a child, the mischief behind the desire to increase the age - that 16 and 17-year-olds may naively allow people to take sexualised photographs of themselves - would now be protected by the new 'revenge pornography' laws. ${ }^{52}$ The new law criminalises the disclosure of a private sexual photograph with intent to cause

46 The Internet Watch Foundation estimate that c. $80 \%$ of the images that they identify as child pornography involve a child who appears to be under the age of 10 (IWF Annual Report 2014 p.9).

47 Hansard, HL Deb, vol 616, col 1566, 04 October 2000.

48 Paedophile has a clinical definition which relates to the sexual attraction to pre-pubescent children: see Seto, n 24 above.

49 See M.A. McCarthy and R.A. Moodie 'Parliament and pornography: the 1978 Child Protection Act' (1981) 34 Parliamentary Affairs 47-62.

50 A picture that shows any sort of sexual contact with a child under 16 would document a crime since the child cannot consent to that act. An image that simply shows the child posing naked or topless would not document a crime (as it is not illegal for a child to be naked). The criminalisation of simple nudity has been debated for some time (see A.A. Gillespie Child Pornography: Law and Policy (2011, Routledge) 57; S. Ost, Child Pornography and Sexual Grooming: Legal and Societal Responses (2009, Cambridge) 132-135.

51 Research has demonstrated that once a sexualised image is released onto the internet then it is unlikely to ever be recovered because it will be downloaded, duplicated, mirrored and reposted (M. Taylor and E. Quayle Child Pornography: An Internet Crime (2003, Routledge) 24).

52 Criminal Justice and Court Services Act 2015, ss.33-35. Arguably certain other laws (most notably s.1, Malicious Communications Act 1988; s.127, Communications Act 2003 and s.2, Protection from Harassment Act 1997 (see AMP v Persons Unknown [2011] EHWC 3454 (TCC) which, whilst a civil case, demonstrates a potential use of the 1997 Act)) would also apply but this new law is perhaps the most pertinent 
distress. Whilst there are some concerns over the extent of the new law, ${ }^{53}$ it will broadly cover those situations where a person, in order to cause distress, discloses to another a sexual photograph of the victim.

16 and 17 year-olds are taking sexualised photographs of one another, as indeed do adults. ${ }^{54}$ The automatic criminalisation of photographs of those under 16 can be justified as it is the picture of an illegal act, but if it is not illegal for two 16-year-olds to have sex with each other, why should a picture of the same be criminalised? If it is a worry that the image will be leaked then the new offence would criminalise such conduct and therefore that protection is now offered.

\section{Sexual Offences Act 2003}

The SO(A) 2000 offences were repealed and replaced by the Sexual Offences Act 2003 (SOA). The new provisions cover two classes of offences; abuse of trust ${ }^{55}$ and familial child sex offences. ${ }^{56} \mathrm{It}$ is not possible in a chapter of this size to consider the detail of these offences in depth and reference should be made elsewhere for critique of these provisions. ${ }^{57}$ Also, for reasons of space we will not consider the familial offences as these raise subtlety different issues. Whilst both concern the 'higher' age, the justification differs between those relating to an abuse of a position of trust and those relating to prohibiting sexual contact with a family member. Focusing on the abuse of a position of trust allows greater scrutiny of these issues in the limited space but we acknowledge that there are concerns as to whether the familial offences criminalise conduct appropriately. ${ }^{58}$

The SOA 2003 widened the criminal liability in respect of an abuse of a position of trust. In essence it replicated certain offences against the child ${ }^{59}$ but raised the age of a victim to 18 . Peculiarly a lesser sentence is given for these offences ${ }^{60}$ which indicates that despite the statutory wording (which suggests it applies to a victim of any age under 18), the offences should ordinarily only be used for victims aged 16 or $17 .{ }^{61}$ This is perhaps confirmed by the fact that abusing a position of trust becomes an aggravating factor for the offences under ss.9-12, ${ }^{62}$ despite the fact that the term is not actually defined in the Sentencing Council's guideline.

As with the SO(A)A 2000, the term 'position of trust; is given a statutory definition through an inclusive list. The first four are the same as in the SO(A)A 2000, although in terms of educational

53 See, for example, A.A. Gillespie " "Trust me, it's only for me": "Revenge Porn" and the Criminal Law' [2015] Crim LR 866-880.

54 See, for example, K. Adbury and K. Crawford 'Sexting, consent and young people's ethics' (2012) 26 Continuum 463-473.

$55 \quad$ Sexual Offences Act 2003, ss.16-24.

$56 \quad$ Ibid., ss.25-29.

57 The leading text on this area is P. Rook and R. Ward Rook and Ward on Sexual Offences (4th Edn, London: Sweet \& Maxwell).

58 See, for example, J.R. Spencer 'The Sexual Offences Act 2003: (2) Child and Family Offences' [2004] Crim LR 347-360 and for a more general critique of criminalising familial abuse see, for example, J.A. Roffee No Consensus on Incest? Criminalisation and Compatibility with the European Convention on Human Rights' (2014) 14 Human Rights Law Review 541-572.

59 Sexual Offences Act 2003, ss.9-12.

60 Compare, for example, sexual activity with a child (s.9, 14 years' imprisonment) and sexual activity with a child whilst in a position of trust (s.16, 5 years' imprisonment).

61 With the substantive offences in ss.9-12 being used for younger victims.

62 See Sexual Offences: Definitive Guideline (2013: Sentencing Council) pp.45-60. 
establishments there is no longer a requirement that the child is in full-time education. ${ }^{63}$ Other positions within the Act would include:

- The provision of certain careers advice within educational establishments but only where the adult looks after the child on an individual basis.

- Where a child is accommodated by the local authority and the adult has regular unsupervised contact with the child.

- Where a person is employed to make a report on the child's welfare for the purposes of proceedings under the Children Act 1989.

- Where a person is engaged to become a personal advisor for the purposes of the Children Act 1989 and the adult looks after B on an individual basis.

- Those who look after a child who is the subject of a care or supervision order under the Children Act 1989.

- Where the adult has been appointed the guardian ad litem of the child and regularly has unsupervised access with the child.

- Where a child has been released from gaol or is under an order from a criminal court (ie the child is either on licence or under a community order) and the adult looks after the child on an individual basis. ${ }^{64}$

The SOA 2003 cured some loopholes, most notably the issue of a probation officer, but left many untouched or criminalised them in a partial way. For example, a number of these situations require the adult to be looking after the victim on an individual basis which may not always be realistic, or where the child has 'regular' unsupervised access to the child. It is not immediately clear why the position of trust is only triggered by unsupervised access to a child and not also in those situations where there is supervised access. Presumably the thought was that supervised access means that the adult would not be in a position to influence the child inappropriately but in the era of modern communication technologies, this can no longer be said to be true. $\mathrm{D}$ may have supervised access to a child but if she then contacts the child through social media (or allows the child to contact her) and they interact in a sexual way subsequent to this, the wrong is equally present even though the offence may not. ${ }^{65}$

An example of those situations that have been left untouched would include the situation of a GP having sexual intercourse with a 17 -year-old patient discussed above. ${ }^{66}$ As the SOA 2003 follows the logic of the SO(A)A 2000 by providing a finite list, if an activity is not included on the list then it does not constitute an abuse of trust even if it is an exploitative relationship. For example, private tutors are not covered by this rule so if a school teacher from another school is employed by a parent to provide additional tuition to their son for A-levels and that teacher then has sexual intercourse with the son, this would not be covered under the 2003 Act. There is, at the very least, a potential abuse of trust in such circumstances that the SOA provisions fail to address.

$63 \quad$ Sexual Offences Act 2003, s.21(5).

64 Sexual Offences Act 2003, s.21(6)-(13) inclusive.

65 Where the child is aged 16 or over then such conduct would not be captured by the so-called 'grooming' offences (Sexual Offences Act 2003, ss.14-15).

66 Whilst, of course, this would constitute serious professional misconduct for disciplinary purposes, it would not be addressed by the criminal law unless factual consent was in issue. See further S. Ost and H. Biggs, '“Consensual" sexual activity between doctors and patients: a matter for the Criminal Law?' in A. Alghrani, R. Bennett \& S. Ost (eds.), The Criminal Law and Bioethical Conflict: Walking the Tightrope (2012, Cambridge) 102-117. 
It has also been noted that if it was decided that criminalising ostensibly consensual sexual activities with 16 and 17 year-olds is correct, ${ }^{67}$ criminalising it in the way that the SOA 2003 does is a peculiar way of going about it. Nine sections and four new offences were created and yet the substantive offences could have been used, simply raising the age of the victim when a position of authority or trust was identified ${ }^{68}$ However this would arguably not have resolved the key weakness of the offence, which is that by defining 'abuse of trust' in a finite way, obvious situations are missed. That perhaps means that the legislature should have focused on something different.

\section{The Concept of Sexual Exploitation}

It has been noted that the current method of protecting 16-18 year olds is flawed. By focusing on the age of the child (as a consent issue), it becomes quickly impractical to think about and list every situation where there may be the risk of abuse or exploitation due to the misuse of authority. Instead of treating this as an issue of age, it may be preferable to consider refocusing attention away from (legal) consent to the concept of exploitation.

\section{What is sexual exploitation?}

Exploitation is a term often banded about but its utilisation is not commonly accompanied by an analysis of what exactly is meant by the concept. ${ }^{69}$ That said, the meaning of exploitation has been scrutinised within philosophical literature, to which we now turn briefly. According to Feinberg, "(e)xploitation in the usual pejorative sense is the wrongful turning to some advantage by one party (A) of some trait or circumstances of another party (B)'. ${ }^{70}$ In common with similar understandings of the concept ${ }^{71}$ Feinberg's definition reveals how exploitation amounts to a violation of the humanity formulation of Kant's second categorical imperative, the ethical responsibility to treat individuals as ends in themselves, rather than merely as means to an end. ${ }^{72}$ Put simply, the exploiter fails to respect the individual he exploits as a person.

Turning specifically to sexual exploitation, in 2003 the (then) Secretary-General of the UN defined sexual exploitation as 'any actual or attempted abuse of a position of vulnerability, differential power, or trust, for sexual purposes, including, but not limited to, profiting monetarily, socially or politically from the sexual exploitation of another. ${ }^{73}$ This definition

67 And it should be noted not everyone agrees that it is: see, for example, Spencer, n 58 above, at 356 and Waites, n 27 above, at 193 et seq.

68 Spencer, n 58 above, at 59.

69 'Too often, uses of exploitation less explain than presuppose the conception applicable.' R Bigwood, Exploitative Contracts (Oxford University Press, 2003), 1. We are concerned here with exploitation we morally disapprove of, rather than in a non-moral context. See S Wilkinson, Bodies for Sale: Ethics and Exploitation in the Human Body Trade (Routledge, 2003), 10.

70 J. Feinberg, The Moral Limits of the Criminal Law: Harmless Wrongdoing (Oxford University Press, 1988), 192 (our emphasis).

71 R. E. Goodin, 'Exploiting a Situation and Exploiting a Person', in A. Reeve (ed.), Modern Theories of Exploitation (Sage, 1987), 166, 182; J. Wolff, 'Marx and Exploitation' (1999) 3 The Journal of Ethics, 105, 11011; A. Wertheimer, Exploitation (Princeton University Press, 1996), 16.

72 I. Kant, Groundwork of the Metaphysics of Morals. In I. Kant and ed. M.J. Gregor, Practical Philosophy: (The Cambridge Edition of the Works of Immanuel Kant) (Cambridge University Press, 1999), 37. See also A, Buchanan, Ethics, Efficiency, and the Market (Rowman and Allanheld, 1985), 87: 'to exploit a person involves the harmful, merely instrumental utilization of him or his capacities, for one's own advantage or for the sake of one's own ends.'

73 Secretary-General's Bulletin, Special measures for protection from sexual exploitation and sexual abuse' ST/SGB/2003/13. Available at: https://cdu.unlb.org/Portals/0/Documents/KeyDoc4.pdf 
captures profiting in some way from another's weaker position and emphasises elements of trust, vulnerability and an imbalance of power. Sexual exploitation constitutes particularly serious wrongful exploitation because of the trust that the level of intimacy involved in sexual activity so often entails. ${ }^{74}$ Moreover, the breach of trust involved makes the effects of sexual exploitation particularly harmful. ${ }^{75}$

Respecting and not violating an individual's autonomy is an integral part of our recognition of them as a person. Hence, the wrong of violating autonomy that so often accompanies sexual exploitation is commonly emphasised. For instance, in Archard's words:

... sexuality is an area in which it is particularly important to treat one another as ends, that is to take into account and respect a person's wishes and beliefs. We are acutely aware of the dangers of failing to do so, and to that extent regard full, knowing, and considered consent as a prerequisite or at least ideal requirement of intimacy. ${ }^{76}$

It is thus unsurprising that consent is the tool by which we appraise whether a person engages willingly in sexual activity, albeit it is a much disparaged legal and moral means of assessment and we have already noted the difficulties raised by consent in the context of older children and varying levels of capacity. Moreover, the mere existence or lack of consent cannot be the only element scrutinised to ascertain whether both parties act in accordance with the afore-mentioned formulation of Kant's categorical imperative. ${ }^{77}$ To return to one of our earlier examples involving $\mathrm{V}$ and her instructor Ms X, both parties may consent, but V may do so because of Ms $\mathrm{X}$ 's deliberate use of her more powerful position to make $\mathrm{V}$ feel that she cannot refuse Ms X's sexual advances, or to impede V's choice so that she considers consent to be her only option, or to make it very difficult in some other way for $\mathrm{V}$ to refuse. This might occur, for instance, in a situation of blackmail, ${ }^{78}$ where Ms X threatens to send V's work to a particularly strict examiner if she does not have sex with her, or in a situation involving an inducement, where Ms X offers to provide $\mathrm{V}$ with private tuition in exchange for sex, for example. Such sexual exploitation is most likely to be present when there is an imbalance of power between the parties as there is between Ms X and V, and the "powerful" person abuses the position of authority by inducing the "dependent" person into' sexual activity. ${ }^{79}$ Whilst the circumstances may well be enough to cause us to question how real Y's consent actually is, ${ }^{80}$ our moral objection is inextricably connected to the way in which consent is induced through Ms X's manipulation of her more powerful position, her exploitation of $\mathrm{V} .{ }^{81}$

$74 \quad$ D. Archard, 'Exploited Consent' (1994) 25 Journal of Social Philosophy, 92, 99.

75 See S Ost, Breaching the Sexual Boundaries in the Doctor-Patient Relationship: Should English Law Recognise Fiduciary Duties?' forthcoming, Medical Law Review.

$76 \quad$ See Archard n 74 above.

77 Indeed, philosophical literature recognises that that one can consent and still be exploited. See, eg, Wolff $\mathrm{n}$ 71 above, 113. For an interesting view that where there is no consent, we would not commonly have exploitation, see Wilkinson 2003: 74.

78 See Ost $\mathrm{n} 75$ above.

79 P. Coleman, 'Sex in Power Dependency Relationships: Taking Unfair Advantage of the "Fair" Sex', (1988) 53 Albany Law Review, 95, 96.

80 Some have gone so far as to argue that in any situation where there is a relationship of 'power dependency', the weaker party's consent to sexual activity is always questionable. See Coleman, ibid., and T. Allen, 'Civil liability for Sexual Exploitation in Professional Relationships' (1996) 59(1) Modern Law Review 56, 58. See Archard's conceptions of 'manipulated consent' and 'exploited consent': Archard 1994: 94-94. 
Notably, such an imbalance of power is present and potentially exploitable in the context of relationships between adults and children, as well as instructors and students, doctors and patients, ${ }^{82}$ clergypersons and parishioners, for example, with trust being a further, integral element of such relationships. Whilst a difference in the age of the parties might be one of the reasons for the existence of an imbalance of power, it could also be caused to exist by a difference in status, or a particular vulnerability that makes one party weaker and thus more susceptible to being taken advantage of.

\section{Criminalising Sexual Exploitation}

How then can you capture an offence that criminalises sexual exploitation? The amended SOA 2003 purports to criminalise the sexual exploitation of a child although it does so only in respect of children who are prostituted and those who are involved in (child) pornography. ${ }^{83}$ This is overly restrictive and is improperly worded. This is not sexual exploitation, this is a type of sexual exploitation.

We have argued that the SOA(A) 2000 and SOA 2003 got into problems by providing a statutory list of what amounted to an abuse of trust. That is nonsensical as whether someone is in a position of trust (or, to adopt our logic, in an exploitative situation) will differ on the circumstances. Rather than providing a list of situations that are exploitative, with the obvious risk of such a list being under or over inclusive, we believe that it would be better to have a statutory test that is linked to a specific crime. In that way it is possible to ensure that the offence covers those who are being exploited, but does not include situations where no exploitation of a position or position of authority exists.

\section{Learning from Canada}

English law could, in our view, learn lessons from Canada. Rather than adopt a list of situations that constitute abuse or exploitation, the relevant statutory provision instead adopts a single test. The legislation is set out in s.153 of the Criminal Code, which states:

Every person commits an offence who is in a position of trust or authority towards a young person, who is a person with whom the young person is in a relationship of dependency or who is in a relationship with a young person that is exploitative of the young person, and who:

(a) for a sexual purpose, touches, directly or indirectly, with a part of the body or with an object, any part of the body of the young person; or

(b) for a sexual purpose, invites, counsels or incites a young person to touch, directly or indirectly, with a part of the body or with an object, the body of any person, including the body of the person who so invites, counsels or incites and the body of the young person. ${ }^{84}$

\footnotetext{
$82 \quad$ See Ost and Biggs n 66 and Ost n 75 above.

83 Sexual Offences Act 2003, ss.47-50 as amended by the Serious Crime Act 2015. For a discussion on whether these offences are needed A.A. Gillespie 'Prostitution or abuse? The Sexual Offences Act 2003' [2005] Crim LR 285-289, which remains a valid criticism as the new offences do not affect the basic structure of those that they replace. 
This is a more comprehensive offence than the comparable English offences. The offence applies only to those aged $16-18^{85}$ and covers all the sexually exploitative activity in a single offence rather than creating separate, overlapping offences (as the English offences do). Rather than list specific circumstances that are deemed to be exploitative in order to determine whether the relationship is appropriate, the judge is encouraged to consider specific points, namely:

(a) the age of the young person;

(b) the age difference between the person and the young person;

(c) the evolution of the relationship; and

(d) the degree of control or influence by the person over the young person. ${ }^{86}$

The latter factor is particularly interesting. It allows judges to look at the circumstances of the relationship and not whether it is included within a particular list. Applying this test, it is likely that relationships such as the GP example discussed above would be caught by the Canadian legislation. Clearly a GP would exercise a high degree of control or influence over a young person and any relationship between them is likely to be considered inappropriate and exploitative. What is more, it is difficult to see how any of the situations set out in the Sexual Offences Act 2003 would not also be captured by the Canadian law. The Canadian law would, as already noted, go further in its reach.

In the discussion of English law we noted that an employer/employee relationship would not be caught by the abuse of a position of trust laws. An employer/employee relationship is not automatically exploitative, but it certainly has the potential to be and offers a sexual exploiter the scope to exert a high level of coercion. Canadian law would recognise this. Nothing in s.153 requires the court to find that a relationship is exploitative, it simply empowers them to do so when the circumstances and context of the relationship are known. Where an employer is seeking sexual contact with an employee and makes an implicit or otherwise link to their future career, probation or promotion then that could be considered exploitative. Similarly, we presented the hypothetical private tutor who enters into sexual activity with a child assigned to him. The nature of this relationship means that it could well be exploitative, particularly where, for example, the tutor is aware that the parents believe that the child is under-performing educationally and are punishing the child for the same.

The flexibility of the offence under s.153 is illustrated by some of the cases that have been decided under it. In $R v O(C P)^{87}$ the offence applied where the father of a friend of the victim had sexual contact with her when she had sleepovers at his house. The court held that the defendant was exercising authority over the child when he stayed at his house. This type of case would not be covered by the English offences and yet this is perhaps a classic example of when there may be de facto trust and an imbalance of power that would call into question the consent given by the child.

In $\mathrm{R} v \mathrm{Edwards}^{88}$ the offender was a dance-class instructor. He paid particular attention to a 14year-old girl who attended his dance classes and ultimately had sexual intercourse with her. The court was clear that this amounted to an exploitative relationship, not least because of the circumstances regarding how the defendant and victim knew each other. Under English law this would not be considered an abuse of a position of trust because it did not take place in an educational establishment that $\mathrm{V}$ attended.

Ibid., s.153(2).

Ibid., s.153(1.2).

(1993) 124 NSR (2d) 366.

(2003) 172 CCC (3d) 313. 
A more troubling, but equally important, case is $R v G(C) .{ }^{89}$ A 27 -year-old man was living in a (shared) house when a 14-year-old girl who had ran away from home came to squat. He was aware of her age and that she had ran away from home and they had sexual intercourse daily. The child testified that the defendant was responsible for providing shelter to her and providing food etc. The Court of Appeal held that this was an exploitative relationship, partly due to the difference in age but also because $\mathrm{V}$ was undoubtedly dependent on $\mathrm{D}$. It is unclear that a similar result would occur in England. ${ }^{90}$ The only potential argument is that this is a case of child prostitution $^{91}$ although (a) this would be controversial ${ }^{92}$ and (b) it is unclear whether such an argument would succeed. ${ }^{93}$ It is submitted that it would be preferable and much more of an accurate reflection of the situation to adopt the approach adopted in Canada of simply considering it an exploitative relationship.

\section{Conclusion}

It is acknowledged that some people are not convinced that it is appropriate to operate two ages of consent. Some have argued that the abuse of trust provisions are unnecessary and were a political sop to those who were opposed to reducing the homosexual age of consent. ${ }^{94}$ However we disagree. Waites has noted that whilst it is not possible to say that every child-adult relationship will be intrinsically harmful, such relationships are undoubtedly risky, and he suggests that this justifies an age of consent. ${ }^{95}$ We would take this further and suggest that this logic justifies criminalising certain relationships between adults and young people over the ordinary age of consent. However the current (English) law operates on the basis that a limited number of certain defined relationships are always harmful and should be prohibited. Even if this could be proved, and it is less than clear that this is the case, it leaves a number of other abusive relationships unregulated. That does not protect vulnerable young people and there are simply too many exceptions because of the blunt way that the law currently operates.

England should learn from Canada and focus not on a list of positions but instead consider whether the actual relationship between the youth and the adult is exploitative. This will involve a number of factors but, at its heart, will be whether the adult has any undue control or influence over the youth. If they do then it can be legitimately questioned whether a child is truly able to give full, knowing and considered consent. Our objection to accepting that the child's consent is genuine is undoubtedly connected to the way in which it has been obtained by the adult's manipulation of power and exertion of control or influence, thereby undermining the capacity of the child to decide whether to engage in sexual activity. This is worthy of protection under the criminal law. To that extent a higher age of consent can be justified but not when applied uniformly. If the specific circumstances of the relationship are examined and evaluated and found to be exploitative then consent is likely to be vitiated and criminal liability can be justified.

$89 \quad$ (1994) 90 CCC (3d) 76.

$90 \quad$ Obviously if $\mathrm{V}$ was 14 a substantive offence could be used, but for the purpose of the argument and focus of this chapter, it is meant that no liability would arise if $\mathrm{V}$ was 16.

91 Sexual Offences Act 2003, s.47 (see, in particular, s.47(2)).
92 Partly because the term itself is problematic and pejorative (see Gillespie, n 83 above, at 285) and partly because it is quite possible/likely that the child may not consider herself to being prostituted.

93 It is reliant on the prosecution proving that $\mathrm{D}$ made or promised payment, which could include the accommodation. On the facts of $\mathrm{R} v G(C)$ it does not seem that this would be easy to prove.

$94 \quad$ Spencer, $\mathrm{n} 58$ above, at 355 .

$95 \quad$ Waites, $\mathrm{n} 25$ above, at 30. 